\title{
UNSUR-UNSUR BUDAYA LOKAL DALAM KARYA ANIMASI INDONESIA PERIODE TAHUN 2014-2018
}

\author{
Andrian Wikayanto \\ Mahasiswa Magister Desain \\ FSRD, Institut Teknologi Bandung \\ No.Hp.: 0895410829991,E-mail:wikayanto@gmail.com \\ Banung Grahita \\ Dosen FSRD, Institut Teknologi Bandung \\ No. Hp.: 08122170044, E-mail: banung.grahita@gmail.com \\ Ruly Darmawan \\ Dosen FSRD, Institut Teknologi Bandung \\ No.Hp.: 0818625823, E-mail: ruly.darmawan@gmail.com
}

\begin{abstract}
ABSTRAK
Identitas budaya lokal di suatu negara memengaruhi bagaimana bentuk dari karya animasi di negara tersebut. Jepang memiliki 14 kategori budaya dan Malaysia memiliki 13 kategori dalam karya animasi mereka. Hal tersebut membuat karya animasi mereka memiliki ciri khas di mata penonton animasi. Di Indonesia, hal tersebut masih belum terpetakan secara mendetail hingga saat ini. Oleh karena itu, penelitian ini mengkaji seperti apa unsur-unsur budaya lokal yang ada dalam karya animasi Indonesia. Metode yang digunakan adalah menggunakan analisis isi dengan pendekatan budaya sebagai landasan teori. Hasil yang didapatkan adalah 17 katagori budaya termasuk 5 kategori yang tidak ada dalam kategori budaya animasi Jepang dan Malaysia. Tujuh belas kategori tersebut tersebar ke dalam 375 bentuk-bentuk identitas budaya yang merepresentasikan ciri khas budaya Indonesia.
\end{abstract}

Kata kunci: animasi Indonesia, representasi budaya, identitas, ciri khas

\section{ABSTRACT}

Local Culture Elements in Indonesian Animation Works in the Period of 2014-2018. Local cultural identity in a country influences the form of animation works in that country. Japan has 14 cultural categories and Malaysia has 13 categories in their animation works. This makes their animation work has distinctive characteristics for the audience. In Indonesia, this still has not been mapped in detail to date. Therefore, this research examines what elements of local culture exist in Indonesian animation works. The method used is content analysis with a cultural approach as the basis of the theory. The results showed that there are 17 cultural categories including 5 categories which do not exist in the cultural category in Japanese and Malaysian animation. Those 17 categories are spread into 375 forms of cultural identity that represent the characteristics of Indonesian culture.

Keywords: Indonesia animation, cultural representation, identity, characteristic 


\section{PENDAHULUAN}

Setiap karya seni yang dibuat oleh manusia merupakan cerminan dari budaya yang ada di sekitarnya. Representasi budaya tersebut dapat dipengaruhi oleh pengalaman hidup, kondisi lingkungan sekitar, agama, suku/etnis dan kebangsaannya (Ahmad, 2008).

Representasi tersebut memungkinkan manusia untuk membentuk karakter dan identitasnya sendiri sembari tetap melestarikan budaya lokal sebagai pengaruh utamanya. Jika ditarik dalam ranah animasi dapat dikatakan bahwa setiap kreator animasi akan membawa identitas budaya dengan kadar tertentu dalam setiap karya animasi sebagai wujud dari eksistensi representasi budaya yang ada di sekitarnya. Dengan kata lain, setiap animasi mencerminkan pengaruh-pengaruh situasi sosial dan budaya di tempat animasi itu dibuat.

Keunikan dari budaya lokal suatu bangsa dapat dijadikan sebagai inspirasi dalam menciptakan konten animasi yang berbasis kedaerahan, namun tetap memiliki bahasa global (Rochman \& Subiyantoro, 2015). Jepang merupakan contoh ideal kebudayaan lokal banyak dieksplor untuk dijadikan sebagai fondasi dalam membuat sebuah konsep animasi. Pada awalnya animasi Jepang banyak terinspirasi dari animasi Amerika khususnya Disney baik dalam penggambaran karakter, teknik animasi, maupun cara berceritanya. Namun, pada akhirnya animasi Jepang dapat membentuk karakteristik atau ciri khas animasi mereka sendiri baik dari segi naratif maupun segi sinematik yang sangat berbeda dengan ciri khas animasi Amerika (Cavallaro, 2010). Bahkan tidak sedikit dari anime tersebut yang berisikan nilai-nilai moral masyarakat Jepang dan pelajaran-pelajaran yang dapat dijadikan sebagai contoh dan diterapkan dalam kehidupan sehari-hari (A. Nugroho, Hendrarastomo, dan Nugraha, 2017). Dari contoh kasus perkembangan anime tersebut, bisa diambil benang merah bahwa betapa kekayaan budaya suatu bangsa ternyata sangat memengaruhi aspek naratif dan sinematik dalam sebuah karya animasi. Dengan demikian, jika Jepang memiliki ciri khas animasi karena lokalitasnya, dapat diduga kuat terdapat ciri khas animasi lain yang tidak kalah menarik di sisi dunia yang lain.

Indonesia juga memiliki potensi yang sama untuk bisa sejajar dengan anime Jepang karena memiliki banyak sekali identitas budaya lokal dari ujung Aceh sampai ujung Papua. Dengan kekayaan budaya tersebut akan sangat mungkin untuk membuat sebuah karya animasi yang terinspirasi oleh budaya yang ada di sekitar masyarakat Indonesia (Sugihartono, 2018). Pendapat ini diiyakan oleh Hikmat Darmawan dalam "Workshop Animasi Untuk Studio Animasi In House" di Kompas TV tahun 2012 yang menyatakan bahwa lokalitas adalah sebuah unsur penentu corak keunikan animasi di sebuah wilayah atau negeri (Darmawan, 2012). Dengan demikian, keunikan budaya tersebut dapat digunakan sebagai parameter yang membedakan karya animasi Indonesia dengan karya animasi dari luar negeri tanpa harus mengesampingkan selera pasar atau penonton.

Sejarah animasi Indonesia juga terinspirasi dari animasi Amerika yang dimulai sejak Presiden Soekarno mengutus Dukut Hendronoto untuk belajar animasi di Disney Amerika selama tiga bulan pada tahun 1955 (Prakosa, 2010). Secara umum banyak kreator animasi lokal Indonesia yang terinspirasi dengan gaya animasi Jepang dan Amerika, namun sudah ada usaha dari para 
kreator animasi Indonesia untuk memasukkan unsur-unsur budaya lokal Indonesia ke dalam karya animasinya meskipun detail dari wujudwujud tersebut masih belum terpetakan hingga sekarang (Wikayanto, 2018). Dengan demikian, dengan sejarah panjang Indonesia dalam dunia animasi tersebut (64 tahun), seharusnya saat ini sudah terlihat bagaimana karakteristik atau ciri khas animasi Indonesia itu sendiri. Namun, sayangnya hingga saat ini masih belum teridentifikasi dengan jelas apa yang membuat animasi Indonesia terlihat "Indonesia" yang merupakan cerminan dari unsur-unsur budaya Indonesia dalam karya animasi tersebut. Identifikasi ini menjadi sangat penting untuk dilakukan karena merupakan tahap awal yang harus dilakukan sebelum mengetahui seperti apa yang menjadi ciri khas/karakteristik animasi Indonesia. Oleh karena itu, penelitian ini mengidentifikasi seperti apa unsur-unsur budaya lokal Indonesia yang sudah dimasukkan oleh kreator animasi Indonesia ke dalam karya animasinya.

\section{PENELITIAN SEBELUMNYA}

Secara khusus Gilles Poitras telah menemukan 14 kategori budaya yang teridentifikasi sebagai representasi identitas budaya Jepang (Poitras, 2005). Kategori tersebut didapatkan dengan menganalisis karya-karya anime dan manga yang ada di negara tersebut. Di sisi lain terdapat pula penelitian yang mengkaji bagaimana bentuk-bentuk identitas budaya dalam karya animasi Malaysia. Pada tahun 2014, penelitian yang dilakukan oleh Mohd Amir Mat Omar \& Md. Sidin Ahmad Ishak menyimpulkan bahwa terdapat 13 kategori yang menunjukkan identitas budaya lokal Malaysia dalam karya animasi Malaysia (Amir dan Omar, 2014). Penelitian ini juga terinspirasi dari penelitian yang dilakukan oleh Poitras dalam animasi Jepang, yaitu untuk mencari apa yang membuat animasi Malaysia terlihat Malaysia dan unsur-unsur budaya lokal apa saja yang muncul dalam karya animasi Malaysia.

Apa yang sudah dikerjakan oleh Gilles Poitras dan Mohd Amir Mat Omar yang meneliti karakteristik budaya dalam animasi Jepang \& Malaysia dapat digunakan sebagai kerangka dalam menemukan bagaimana karakteristik budaya dalam karya animasi Indonesia dalam penelitian ini. Poitras menemukan terdapat 14 kategori yang ditemukan dalam anime Jepang dan Omar menemukan 13 kategori dalam animasi Malaysia (tabel 1). Jika dilihat dengan saksama, terdapat persamaan dan perbedaan dalam 2 kategori animasi tersebut. Persamaan dan perbedaan tersebut dapat terjadi karena perbedaan sampel dan genre animasi yang digunakan dalam penelitian tersebut. Persamaan dari dua penelitian itu terdapat dalam 9 kategori, yaitu kategori kostum, makanan \& minuman, orang, budaya \& adat istiadat, lokasi geografis, bangunan, struktur \& penanda, agama \& kepercayaan, hiburan \& permainan, dan yang terakhir adalah kategori umum.

Perbedaan dua kategori tersebut adalah dalam kategori sejarah, aktivitas olahraga, rumah, alam, dan senjata perang yang terdapat dalam kategori animasi Jepang. Dalam kategori animasi Malaysia terdapat dalam kategori bahasa \& komunikasi, nilai-nilai, agrikultur, dan lain-lain. 
Tabel 1 Perbandingan kategori animasi Jepang \& Malaysia

\begin{tabular}{lll}
\hline \multicolumn{1}{c}{ Jepang } & \multicolumn{1}{c}{ Malaysia } \\
\hline 1. Clothing & 1. Clothing \\
2. Food and drink & 2. Food \& Drinks \\
3. History/Society & 3. Language \& \\
4. People & & Communication \\
5. Culture & 4. People \\
6. Sport activity & 5. Culture \& Custome \\
7. Home & 6. General \\
8. Geographical & 7. Values \\
Feature & 8. Geographical \\
9. Building/Structure/ & & Feature \& Location \\
& Landmark & 9. Building/Structure/ \\
10. Religion/ & Landmark \\
Mythology/Belief & 10. Religion/ \\
11. Nature & Mythology/Belief \\
12. Entertainment/ & 11. Agriculture \\
13. Game & 12. Entertainment/ \\
13. Weaponry/War & Game \\
\hline 14. General & 13. Others \\
\hline
\end{tabular}

\section{METODOLOGI}

Untuk memahami lebih dalam mengenai identitas budaya Indonesia dalam karya animasi lokal ini digunakan metode analisis isi. Analisis isi sudah banyak dipakai untuk penelitian di bidang komunikasi dan media dengan berbagai tujuan. Analisis isi berupaya untuk mengidentifikasi pola, tema, bias, dan makna melalui penilaian yang komprehensif dan sistematik di bagian tertentu dalam sebuah teks (Mayring, 2014).

Secara khusus penelitian ini akan menggunakan model analisis isi Mayring's Step Model of Inductive Category Development (gambar 1). Mengapa harus memilih pendekatan dalam bentuk induktif? Hal ini karena penelitian ini menguraikan satu per satu karya animasi lokal dan melihat secara mendetail kode-kode budaya apa saja yang muncul dalam karyakarya animasi tersebut secara khusus dan pada akhirnya nanti akan dirumuskan menjadi satu menjadi bentuk kode budaya dalam bentuk yang lebih umum. Berikut adalah langkahlangkah dalam melakukan analisis data dengan menggunakan model ini.

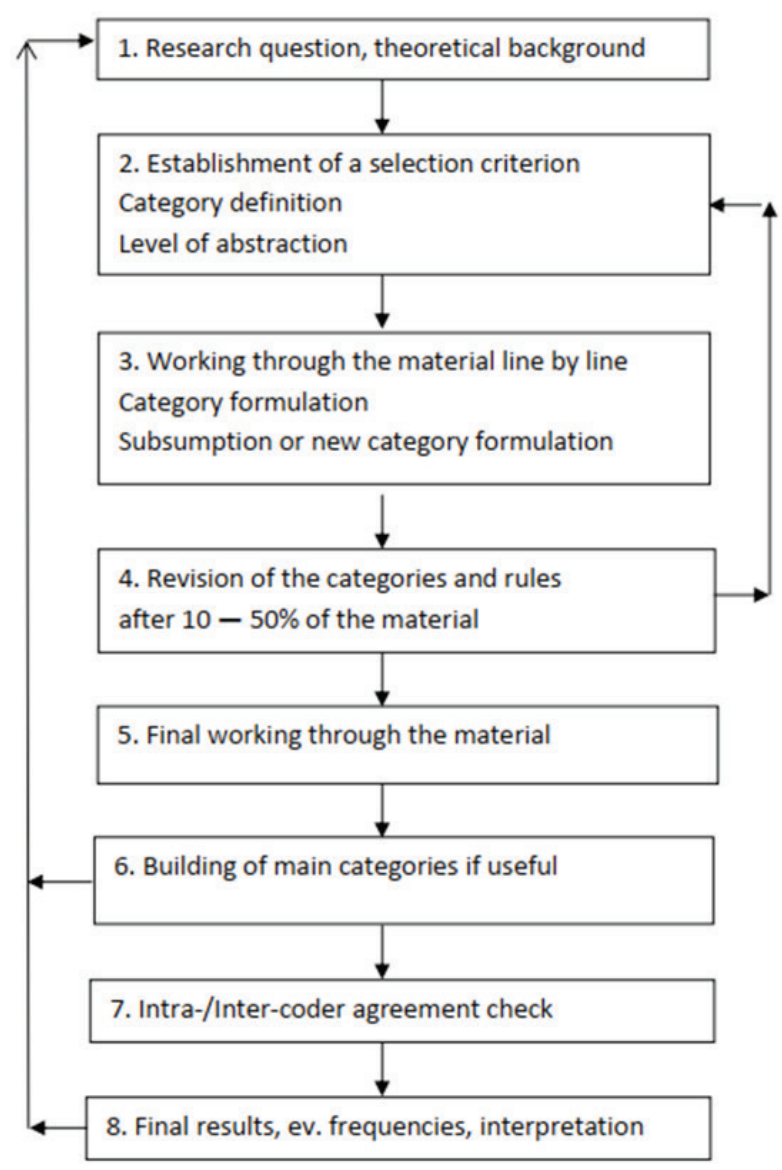

Gambar 1 Model analisis Mayring's Step Model of Inductive Category Development (Mayring, 2014).

Tabel 2 Sampel penelitian

\begin{tabular}{|c|c|c|c|c|c|}
\hline No. & $\begin{array}{c}\text { Judul } \\
\text { Film }\end{array}$ & $\begin{array}{c}\text { Tahun } \\
\text { Produksi }\end{array}$ & $\begin{array}{c}\text { Tema } \\
\text { Cerita }\end{array}$ & Media & Jumlah \\
\hline 1. & $\begin{array}{c}\text { Battle of } \\
\text { Surabaya } \\
\text { (BoS) }\end{array}$ & 2015 & $\begin{array}{l}\text { Sejarah } \\
\text { Indonesia }\end{array}$ & $\begin{array}{c}\text { Film } \\
\text { bioskop }\end{array}$ & 1 film \\
\hline 2. & $\begin{array}{l}\text { Si Juki } \\
\text { The } \\
\text { Movie } \\
\text { (SJ) }\end{array}$ & 2018 & Petualangan & $\begin{array}{l}\text { Film } \\
\text { bioskop }\end{array}$ & 1 film \\
\hline 3. & $\begin{array}{l}\text { Knight } \\
\text { Kris } \\
(\mathrm{KK})\end{array}$ & 2018 & Fantasi & $\begin{array}{l}\text { Film } \\
\text { bioskop }\end{array}$ & 1 film \\
\hline 4. & $\begin{array}{c}\text { Adit } \\
\text { Sopo } \\
\text { Jarwo } \\
\text { (ASJ) } \\
\end{array}$ & $\begin{array}{l}2014- \\
2018\end{array}$ & $\begin{array}{l}\text { Slice of } \\
\text { Life }\end{array}$ & $\begin{array}{l}\text { Serial } \\
\text { televisi }\end{array}$ & $\begin{array}{c}10 \\
\text { episode }\end{array}$ \\
\hline 5. & $\begin{array}{c}\text { Keluarga } \\
\text { Somat } \\
(\mathrm{KS})\end{array}$ & $\begin{array}{l}2014- \\
2018\end{array}$ & $\begin{array}{l}\text { Slice of } \\
\text { Life }\end{array}$ & $\begin{array}{c}\text { Serial } \\
\text { televisi }\end{array}$ & $\begin{array}{c}10 \\
\text { episode }\end{array}$ \\
\hline
\end{tabular}


Karya animasi yang diambil sebagai sampel penelitian adalah animasi buatan studio lokal Indonesia dan disutradarai oleh kreator dari Indonesia pula. Selain itu, karya tersebut haruslah sebuah karya animasi yang sudah pernah tayang di bioskop dan serial televisi di televisi nasional di Indonesia. Hal ini dikarenakan kedua media tersebut adalah media tayang yang paling sering digunakan oleh para pelaku industri animasi di seluruh dunia dan paling banyak dilihat oleh penonton selain di media online (Rall, 2018). Dengan demikian, diharapkan dengan pengambilan sampel karya animasi yang telah tayang di bioskop atau televisi Indonesia dalam penelitian ini merupakan karya animasi yang telah memiliki standar industri dan diproduksi untuk kebutuhan hiburan penonton di Indonesia. Oleh karena itu, penelitian ini akan mengalisis 10 serial animasi Adit Sopo Jarwo, 10 serial animasi Keluarga Somat, 1 film animasi Battle of Surabaya, 1 film Si Juki The Movie, dan 1 film Knight Kris. Pemilihan lima karya animasi Indonesia tersebut dikarenakan secara umum animasi tersebut terlihat banyak memasukkan konten budaya dan identitas masyarakat Indonesia ke dalam bentuk-bentuk audio dan visualnya.

\section{DATA \& DISKUSI}

Seperti yang sudah dijelaskan dalam bahasan sebelumnya bahwa penelitian ini memakai 17 variabel kategori yang didapatkan dari penelitian sebelumnya yang mengidentifikasi karakteristik budaya dalam animasi Jepang dan Malaysia. Penggunaan kategori tersebut jika dilihat merupakan kategori-kategori umum yang bisa jadi juga ditemukan dalam budaya-budaya lain di negara lainnya. Dengan demikian, penggunaan variabel ini hanya digunakan sebagai variabel kategori awal untuk mengidentifikasi unsur-unsur budaya lokal apa saja yang terdapat dalam animasi Indonesia. Jadi, dapat dimungkinkan untuk mengurangi atau menambahkan kategori-kategori baru pada saat melakukan proses identifikasi dalam karya animasi lokal Indonesia.

Pada saat proses analisis terdapat 5 kategori baru yang tidak ada dalam daftar kategori sebelumnya. Kategori baru tersebut adalah suara, transportasi, kesenian, gerakan, dan kenegaraan. Dengan demikian, total terdapat 22 tema kategori yang menandakan ciri khas identitas budaya Indonesia yang tersebar ke dalam 375 bentuk. Berikut adalah 22 tema kategori tersebut: kostum, kuliner, orang, tradisi dan adat istiadat, lokasi geografis, bangunan, struktur dan penanda, agama dan kepercayaan, permainan, sejarah, olahraga, rumah, alam, perang dan senjata, bahasa dan komunikasi, nilai-nilai, agribudaya, properti umum, suara, transportasi, gerakan, kenegaraan, dan kesenian.

Langkah selanjutnya yang dilakukan adalah mencoba untuk mereduksi kategori yang ada dengan menggabungkan beberapa kategori yang dirasakan memiliki kesamaan menjadi satu tanpa menghilangkan esensi utamanya. Kategori budaya \& adat istiadat dan kategori nilai-nilai dijadikan satu menjadi kategori gagasan karena sama-sama merupakan bentuk dari wujud kebudayaan yang abstrak seperti yang dinyatakan oleh Koentjaraningrat (1992). Kategori sejarah dan kategori perang dijadikan satu karena memiliki kesamaan dalam konteks waktu pada masa lalu yang mengiringinya, sedangkan yang termasuk dalam kategori senjata akan dimasukkan dalam kategori properti umum karena termasuk dalam bentuk barang-barang aksesoris. Kemudian kategori permainan dan kategori olahraga dijadikan satu karena dalam kategori olahraga karena sama-sama termasuk 
sebuah kegiatan fisik. Alasan ini dikuatkan dengan hanya ditemukannya dua jenis dalam kategori olahraga, yaitu sepakbola kampung dan kasti yang masih bisa relevan jika dimasukkan ke dalam kategori permainan. Lalu kategori alam digabung dengan kategori letak geografis juga karena dalam hasil temuan memiliki kesamaan yang hampir mirip satu dengan yang lainnya. Kategori terakhir adalah kategori rumah yang digabungkan dengan kategori bangunan, struktur dan penanda yang sama-sama memiliki unsur yang mirip, yaitu bercerita tentang atribut dalam bangunan tempat tinggal yang ada di Indonesia. Dengan demikian, pada tahap reduksi ini akan membentuk 17 tema kategori identitas budaya lokal Indonesia yang didapatkan dari hasil analisis isi dari 5 sampel animasi di atas. Tabel 3 adalah definisi lengkap dari 17 kategori tersebut.

Tabel 3 Kategori dan definisi kategori hasil

\begin{tabular}{|c|c|c|}
\hline No. & Kategori & Definisi Kategori \\
\hline 1. & Kostum & $\begin{array}{l}\text { Segala bentuk pakaian dan aksesoris yang dikenakan dan teridentifikasi } \\
\text { sebagai bentuk dari identitas Indonesia. }\end{array}$ \\
\hline 2. & Kuliner & $\begin{array}{l}\text { Hidangan, resep, alat-alat dapur, bentuk bangunan dan apa pun yang terkait } \\
\text { dengan makanan \& minuman Indonesia. }\end{array}$ \\
\hline 3. & Orang & $\begin{array}{l}\text { Ras, suku, tokoh dan pekerjaan karakter dalam animasi yang mewakili } \\
\text { identitas Indonesia. }\end{array}$ \\
\hline 4 & Alam \& geografis & $\begin{array}{l}\text { Segala sesuatu yang terkait dengan bentuk geologi bumi, tanaman, hewan- } \\
\text { hewan dan menunjukkan tempat, daerah, atau tanda-tanda tertentu yang ada } \\
\text { di Indonesia. }\end{array}$ \\
\hline 5. & $\begin{array}{l}\text { Bangunan, struktur } \\
\& \text { penanda }\end{array}$ & $\begin{array}{l}\text { Objek bangunan buatan manusia yang mewakili atau menunjukkan identitas } \\
\text { Indonesia }\end{array}$ \\
\hline 6. & $\begin{array}{l}\text { Agama \& } \\
\text { kepercayaan }\end{array}$ & $\begin{array}{l}\text { Praktik-praktik atau representasi dari agama dan kepercayaan yang diakui di } \\
\text { Indonesia. }\end{array}$ \\
\hline 7. & Permainan & $\begin{array}{l}\text { Segala aktivitas/kegiatan lokal dan tradisional yang dilakukan untuk } \\
\text { kesenangan oleh orang-orang Indonesia. }\end{array}$ \\
\hline 8. & Sejarah & $\begin{array}{l}\text { Peristiwa atau kejadian pada masa lalu yang terjadi dan terkait dengan } \\
\text { Indonesia. }\end{array}$ \\
\hline 9. & $\begin{array}{l}\text { Bahasa \& } \\
\text { komunikasi }\end{array}$ & $\begin{array}{l}\text { Segala bentuk ucapan, dialek, tulisan serta gerakan komunikasi yang } \\
\text { mencerminkan identitas orang Indonesia }\end{array}$ \\
\hline 10. & Agribudaya & $\begin{array}{l}\text { Pengetahuan, aktivitas atau alat yang berkaitan dengan mencocok tanam dan } \\
\text { peternakan di Indonesia }\end{array}$ \\
\hline 11. & Properti Umum & $\begin{array}{l}\text { Peralatan, benda-benda tradisional atau modern yang sering terlihat disekitar } \\
\text { masyarakat Indonesia }\end{array}$ \\
\hline 12. & Suara & $\begin{array}{l}\text { Segala bentuk audio seperti lagu, alat musik atau suara-suara yang berasal } \\
\text { dan sering terdengar di Indonesia }\end{array}$ \\
\hline 13. & Transportasi & $\begin{array}{l}\text { Segala bentuk alat angkutan baik berupa roda dua, roda tiga atau lebih yang } \\
\text { sering terlihat di Indonesia }\end{array}$ \\
\hline 14. & Gerakan & $\begin{array}{l}\text { Semua kegiatan \& kebiasaan sehari-hari serta dapat berbentuk perilaku } \\
\text { positif \& negatif yang sering dilakukan oleh masyarakat Indonesia }\end{array}$ \\
\hline 15. & Kenegaraan & Lembaga dan tanda yang menunjukkan identitas kenegaraan NKRI \\
\hline 16. & Kesenian & $\begin{array}{l}\text { Semua bentuk ekspresi manusia akan keindahan yang memiliki latar } \\
\text { belakang tradisi atau sistem budaya masyarakat Indonesia }\end{array}$ \\
\hline
\end{tabular}

17. Gagasan 
Untuk memudahkan pencarian dan kategorisasi unsur-unsur budaya Indonesia dalam animasi, dibuatlah pengelompokan berdasarkan jenis-jenis budaya yang masih terkait dan memiliki kesamaan satu dengan yang lainnya. Dengan demikian, dalam satu kategori budaya bisa memiliki lebih dari satu jenis yang masih terkait dengan kategori utama seperti yang terlihat pada tabel lampiran. Berikut adalah tabel frekuensi hasil analisis isi unsur-unsur budaya lokal yang ditemukan pada sampel animasi Indonesia.

Tabel 4 Frekuensi jumlah sebaran kategori unsur budaya lokal pada animasi Indonesia

\begin{tabular}{ccc}
\hline No. & Kategori & Jumlah Item \\
\hline 1. & Agama \& kepercayaan & 32 \\
2. & Agribudaya & 5 \\
3. & Alam \& geografis & 17 \\
4. & Bahasa \& Komunikasi & 36 \\
5. & Bangunan, struktur \& & 31 \\
6. & penanda & 24 \\
7. & Gagasan & 29 \\
8. & Gerakan & 27 \\
9. & Karakter & 14 \\
10. & Kenegaraan & 7 \\
11. & Kesenian & 35 \\
12. & Kostum & 32 \\
13. & Kuliner & 22 \\
14. & Permainan & 24 \\
15. & Properti & 8 \\
16. & Sejarah & 14 \\
17. & Suara & 18 \\
\hline
\end{tabular}

Jika melihat hasil dari analisis isi pada tabel 4 dapat dilihat bahwa identitas budaya Indonesia ditampilkan dalam berbagai bentuk pada sampel animasi yang diteliti. 375 bentuk identitas tersebut merupakan bentuk dari representasi budaya yang sering dijumpai di sekitar masyarakat di Indonesia seharihari. Contohnya secara visual bentuk-bentuk bangunan yang ada di lima animasi tersebut memiliki kesamaan bentuk pada bentuk rumah tempat tinggal yang ada di Indonesia. Kesamaan tersebut terdapat pada bentuk atap yang miring dan dari bahan material yang dipakai pada rumah tersebut. Bentuk atap miring tersebut banyak digunakan pada rumah-rumah yang berada di daerah iklim tropis karena akan memudahkan air hujan saat jatuh ke bawah. Perbedaan yang cukup mencolok terdapat pada penggunaan material pada bangunan rumah tersebut. Meskipun berbeda tahun dalam ceritanya, bentuk rumah dalam film Battle of Surabaya (1945) dengan Adit Sopo Jarwo (2019), Keluarga Somat (2019), Knight Kris (tidak diketahui), dan Si Juki (2018) memiliki kesamaan satu dengan yang lainnya. Yang membedakan hanyalah bentukbentuk desain \& ornamen rumahnya yang berbeda karena pengaruh dari masa atau zaman dalam animasi tersebut seperti dalam film Battle of Surabaya banyak memunculkan bangunan dengan desain khas Eropa peninggalan Belanda. Artinya perubahan bentuk visual pada identitas budaya Indonesia yang muncul dalam animasi dipengaruhi oleh masa/zaman yang diangkat pada tema animasi tersebut. Tidak hanya dalam bentuk bangunannya, namun hal tersebut juga dapat ditemui pada bentuk kostum/pakaian yang dipakai oleh karakter, properti yang ada di dunia animasi tersebut hingga kebiasaan-kebiasaan masyarakat yang berbeda pada setiap zaman.

Hal yang sama juga terdapat pada penggambaran setting lingkungan yang terdapat dalam lima animasi di atas. Kecuali dalam film Knight Kris yang memiliki konsep fantasi, pada Battle of Surabaya, Si Juki, Adit Sopo Jarwo, dan Keluarga Somat banyak memasukkan elemen latar belakang yang merepresentasikan kota Surabaya dan Jakarta. Unsur-unsur tersebut dapat diketahui dari bentuk-bentuk dari bangunan dan latar 
belakang yang dipakai dalam animasi tersebut yang berkaitan erat dengan pemilihan tema dan cerita oleh kreator sebelumnya. Dalam hasil analisis isi wujud tersebut dapat dilihat pada bentuk-bentuk bangunan rumah, tempat ibadah dan bangunan bersejarah, kondisi alam sekitar seperti perumahan, kampung dan pedesaan khas Indonesia, dan dari bentuk-bentuk benda dan properti keseharian seperti wujud visual dari makanan \& minuman khas Indonesia, alat transportasi modern \& tradisional, serta lambang-lambang kenegaraan seperti bentuk mata uang rupiah dan bendera merah putih. Kesemua itu dimunculkan untuk mendapatkan atmosfer yang kuat tentang suasana dan setting lingkungan yang merepresentasikan identitas Indonesia di mata penonton.

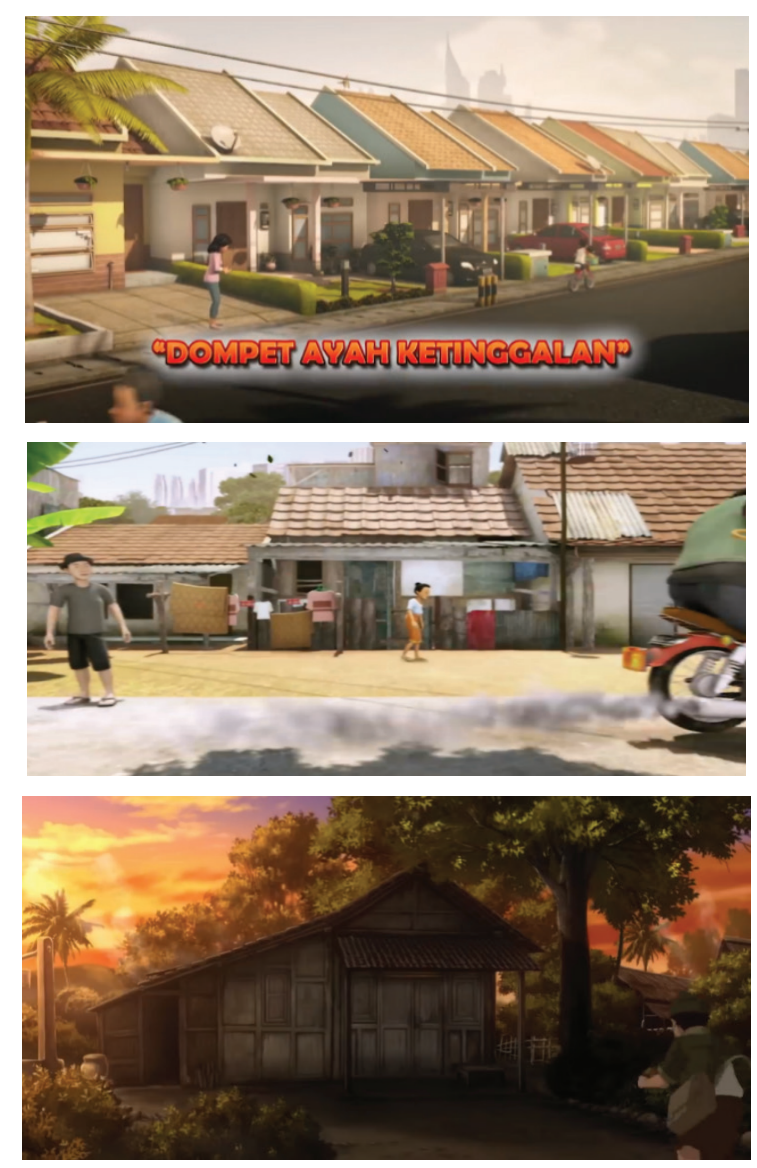

Gambar 2 Visualisasi bangunan rumah yang berbeda pada animasi Indonesia seperti rumah modern di perkotaan (atas), rumah di kampung pinggir kota (tengah) dan rumah tradisional di desa (bawah).

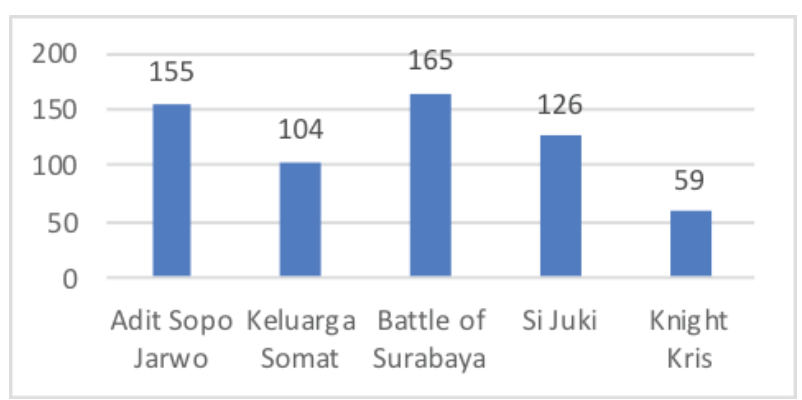

Gambar 3 Data sebaran jumlah item budaya lokal dalam animasi Indonesia

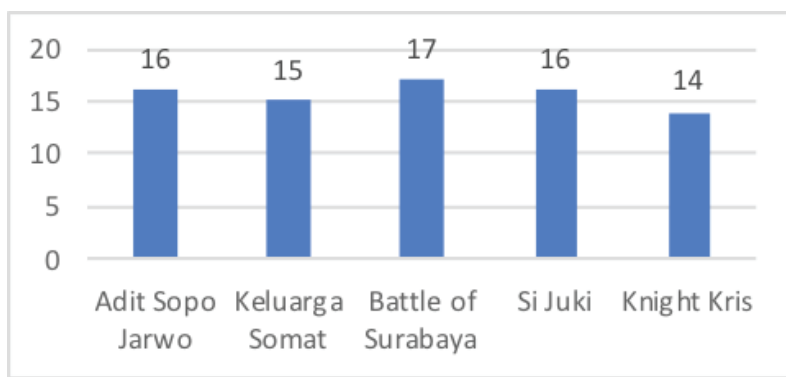

Gambar 4 Sebaran jumlah kategori budaya lokal dalam animasi Indonesia

Dari gambar 3 dan 4 diketahui bahwa untuk kategori serial animasi Adit Sopo Jarwo memiliki jenis ciri khas Indonesia lebih banyak daripada serial animasi Keluarga Somat. Sementara itu, film animasi Battle of Surabaya memiliki jumlah yang paling tinggi di antara 5 karya animasi lokal yang lain meskipun secara visual memakai gaya khas animasi Jepang. Hal tersebut sangat beralasan karena film ini memiliki setting waktu pada tahun 1945 yang notabene pada saat itu banyak sekali barang tradisional dan objek tempo dulu. Jadi, tidak heran hasil produksinya banyak sekali memunculkan unsur budaya lokal Indoensia pada tahun tersebut untuk mendapatkan kesan yang mendalam dalam setting ceritanya.

Film Knight Kris memiliki jenis paling sedikit dari semuanya karena dalam animasi ini lebih banyak fokus pada cerita fantasi, meskipun dibalut dengan visual tentang budaya lokal seperti keris, candi, dan wayang yang kebanyakan penggambaran visualnya berupa campuran dari visualisasi budaya tradisional 
dengan gambar imajinasi dari kreatornya. Film animasi Si Juki memiliki jumlah jenis yang lebih tinggi daripada serial animasi Keluarga Somat. Hal ini menunjukkan bahwa meskipun memiliki durasi yang terbatas, sebuah karya animasi untuk film bioskop bisa memiliki ciri khas identitas Indonesia yang lebih banyak daripada serial animasi yang memiliki keleluasaan dalam jumlah episode dan waktu penayangan.

\section{SIMPULAN}

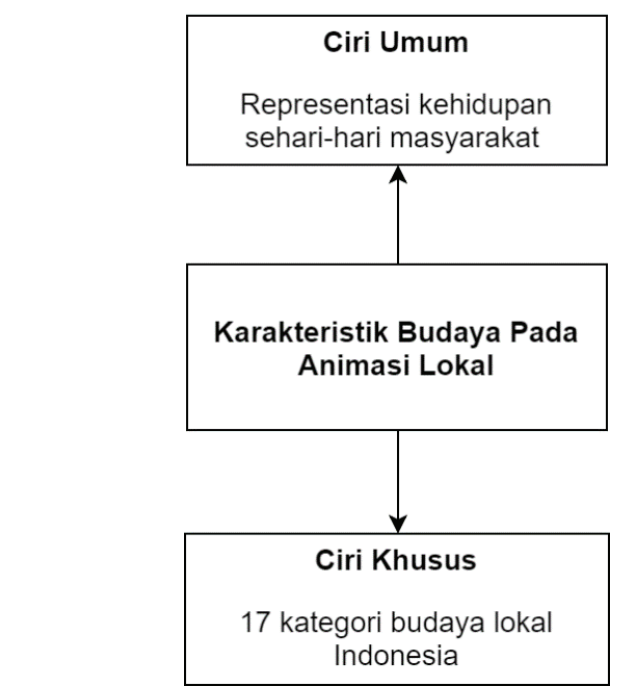

Gambar 5 Wujud karakteristik budaya dalam animasi lokal

Unsur-unsur budaya lokal dalam animasi Indonesia dapat lebih dilihat sebagai upaya kreator dalam menyajikan ulang/ merekonstruksi segala bentuk identitas budaya Indonesia sebagai cerminan realitas di dunia nyata yang mengendap dalam memorinya kedalam media film animasi (Rokhani, Salam and Rochani-Adi, 2016). Dari data yang diperoleh dapat disimpulkan bahwa unsurunsur budaya lokal yang muncul dalam karya animasi buatan anak bangsa dapat dimunculkan dalam berbagai macam wujud/bentuk (gambar 5). Wujud tersebut secara umum dapat berupa representasi dari kehidupan seharihari yang jamak ditemukan di tengah-tengah masyarakat Indonesia baik itu pada waktu zaman modern, zaman tradisional, maupun fantasi yang meliputi tanda-tanda yang tangible dan intangible, verbal dan nonverbal yang mencerminkan karakteristik budaya khas Indonesia. Secara khusus wujud tersebut dapat berupa 17 kategori yang lebih spesifik yang sudah ditemukan dalam 5 sampel karya animasi yang masuk ke dalam 375 bentuk. Karakteristik ini terbentuk dari budaya yang berkembang di tempat animasi tersebut berasal dalam hal ini terdapat di Indonesia.

Dari penelitian ini dapat dilihat bahwa kelima sampel animasi memiliki karakteristik yang tidak terdapat dalam animasi lain dari luar negeri, yaitu dengan banyak memasukkan unsur-unsur budaya lokal Indonesia. Meskipun dalam gaya visual banyak terinspirasi dari animasi luar negeri, jika konten di dalamnya banyak memuat unsur budaya asli Indonesia maka dapat dipastikan bahwa animasi tersebut dapat dikatakan sebagai animasi yang memiliki ciri khas animasi Indonesia. Ciri khas tersebut dapat dipakai sebagai upaya untuk memberikan pengaruh kuat pada pencitraan budaya bangsa di mata penonton (Luthfi, 2018). Oleh karena itu, hendaknya para kreator animasi lokal Indonesia memperbanyak untuk memasukkan identitas budaya Indonesia ke dalam karya animasinya agar dapat membentuk persepsi akan ciri khas animasi Indonesia di benak para penonton animasi dalam dan luar negeri lebih luas lagi pada masa mendatang. 


\section{KEPUSTAKAAN}

A Nugroho, P., Hendrarastomo, G. and Nugraha, P. A. (2017) 'Anime Sebagai Budaya Populer (Studi Pada Komunitas Anime di Yogyakarta)', Jurnal Pendidikan Sosiologi, 6(3), pp. 1-15.

Ahmad, H.A.(2008)A Thesis on Implementation of Culture and its Visual Representation in Indonesian Animation. Based on Case Study of Japanese and Korean Animation. Woosong University.

Amir, M. and Omar, M. (2014) 'Understanding Malaysian Animation Characteristics : A Structuralist -Semiotic Analysis on Malaysian Animation Series', MalaysiaN JourNal of Media studies, pp. 25-37.

Cavallaro, D. (2010) Anime and the Art of Adaptation.

Darmawan, H. (2012) 'Mengapa Animasi?', workshop animasi untuk studio Animasi in house di Kompas TV.

Koentjaraningrat, K. (1992) 'Mentalitas dan Pembangunan di Indonesia', Jakarta: Gramedia Pustaka Utama.

Luthfi, A. (2018) 'Pendidikan Seni Film dan Televisi Menjadi Penggerak Industri Ekonomi Kreatif', REKAM: Jurnal Fotografi, Televisi, dan Animasi, 13(2), p. 99. doi: 10.24821/rekam.v13i2.1933.

Mayring, P. (2014) 'Qualitative Content Analysis', The SAGE Handbook of Qualitative Data Analysis, pp. 170-183. doi: http://dx.doi. org/10.4135/9781446282243.n12.

Poitras, G. (2005) The Anime Companion 2: More What's Japanese in Japanese Animation? Stone Bridge Press. Available at: https://books.google.co.id/ books?id $=5 \mathrm{x}$ mBQAAQBAJ.

Rall, H. (2018) Animation from concept to production. New York: Taylor \& Francis Group.

Rochman, F. and Subiyantoro, H. et. a. (2015) Rencana Pengembangan Animasi Nasional 2015-2019.

Rokhani, U., Salam, A. and Rochani-adi, I. (2016) "Rekonstruksi Identitas ke'Tionghoa'-an dalam Film Indie PascaSuharto". REKAM: Jurnal Fotografi, Televisi, Animasi. 12(1), pp. 55-68.
Steve Roberts (2007) Character Animation: $2 D$ Skills for Better 3D. 2nd edn. Oxford: Focal Press.

Sugihartono, R. A. (2018) 'Developing Indonesian Animation Based on Local Culture', Advances in Economics, Business and Management Research, 41(February), pp. 164-168. doi: 10.2991/ bcm-17.2018.30.

Wikayanto, A. (2018) 'Representasi Budaya dan Indentitas Nasional Pada Animasi Indonesia', in ARTESH. Bandung: FSRDITB. 
Tabel 1

Lampiran Bentuk identitas budaya Indonesia yang muncul pada animasi.

*Adit (Adit Sopo Jarwo), BoS (Battle of Surabaya), KS (Keluarga Somat), KK (Knight Kris), SJ (Si Juki The Movie).

\begin{tabular}{|c|c|c|c|c|c|c|c|c|c|}
\hline Kategori & Jenis & No. & Item/Bentuk & $\begin{array}{l}\text { Unsur } \\
\text { Animasi }\end{array}$ & \multicolumn{5}{|c|}{ Kemunculan } \\
\hline \multirow{32}{*}{$\begin{array}{c}\text { Agama \& } \\
\text { kepercayaan }\end{array}$} & \multirow{8}{*}{ Kalimat keislaman } & 1 & Syukur, alhamdulillah & Audio & Adit & & $\mathrm{KS}$ & & SJ \\
\hline & & 2 & $\begin{array}{l}\text { Salam, assalamu'alaikum \& } \\
\text { wa'alaikum salam }\end{array}$ & Audio & Adit & & KS & & SJ \\
\hline & & 3 & Bismillah & Audio & Adit & & & & \\
\hline & & 4 & Masyaallah (Kaget) & Audio & Adit & & & & \\
\hline & & 5 & Istighfar & Audio & Adit & & & & \\
\hline & & 6 & Insyaallah & Audio & Adit & $\mathrm{BoS}$ & & & \\
\hline & & 7 & Innalillahi & Audio & & $\mathrm{BoS}$ & & & \\
\hline & & 8 & Takbir & Audio & & $\mathrm{BoS}$ & & & \\
\hline & \multirow{2}{*}{$\begin{array}{c}\text { Gaya bicara tokoh } \\
\text { mistis }\end{array}$} & 9 & Suara dukun & Audio & & & & & $\mathrm{SJ}$ \\
\hline & & 10 & Suara hantu lokal & Audio & & & & & SJ \\
\hline & Lagu religi & 11 & Sholawat & Audio & Adit & $\mathrm{BoS}$ & & & \\
\hline & \multirow{8}{*}{$\begin{array}{l}\text { Aktivitas } \\
\text { keagamaan }\end{array}$} & 12 & Berdoa & Gerakan & Adit & $\mathrm{BoS}$ & & & \\
\hline & & 13 & Wudhu & Gerakan & & $\mathrm{BoS}$ & & & \\
\hline & & 14 & Sholat & Gerakan & & $\mathrm{BoS}$ & & & \\
\hline & & 15 & Sahur & Gerakan & & & $\mathrm{KS}$ & & \\
\hline & & 16 & Buka puasa & Gerakan & & & KS & & \\
\hline & & 17 & Berpuasa & Gerakan & & & $\mathrm{KS}$ & & \\
\hline & & 18 & Idulfitri & Gerakan & Adit & & & & \\
\hline & & 19 & Azan & Gerakan & & $\mathrm{BoS}$ & KS & & \\
\hline & \multirow{4}{*}{ Agama } & 20 & Islam & Naratif & Adit & $\mathrm{BoS}$ & $\mathrm{KS}$ & & \\
\hline & & 21 & Kristen & Naratif & & $\mathrm{BoS}$ & & & \\
\hline & & 22 & Konghuchu & Naratif & & $\mathrm{BoS}$ & & & \\
\hline & & 23 & Budha & Naratif & & $\mathrm{BoS}$ & & & \\
\hline & Tokoh agama & 24 & Ulama/kyai/ustad & Visual & Adit & $\mathrm{BoS}$ & & & \\
\hline & \multirow{2}{*}{ Tokoh mistis } & 25 & Dukun & Visual & & & & & SJ \\
\hline & & 26 & Hantu lokal & Visual & & & & & SJ \\
\hline & \multirow{3}{*}{ Tempat ibadah } & 27 & Musholla & Visual & Adit & $\mathrm{BoS}$ & & & \\
\hline & & 28 & Pure bali & Visual & & & $\mathrm{KS}$ & & \\
\hline & & 29 & Candi & Visual & & & & $\mathrm{KK}$ & \\
\hline & Kitab suci & 30 & Alquran & Visual & & $\mathrm{BoS}$ & & & \\
\hline & \multirow{2}{*}{ Properti eligi } & 31 & Tungku wudhu & Visual & & $\mathrm{BoS}$ & & & \\
\hline & & 32 & Kembang 7 rupa & Visual & & & & & $\mathrm{SJ}$ \\
\hline \multirow{5}{*}{ Agribudaya } & $\begin{array}{c}\text { Bangunan } \\
\text { peternakan }\end{array}$ & 33 & Kandang ayam & Visual & Adit & & KS & & \\
\hline & Area pertanian & 34 & Sawah & Visual & & $\mathrm{BoS}$ & & $\mathrm{KK}$ & \\
\hline & \multirow{3}{*}{$\begin{array}{c}\text { Peralatan } \\
\text { agribudaya }\end{array}$} & 35 & Orang-orangan sawah & Visual & & & & KK & $\mathrm{SJ}$ \\
\hline & & 36 & Pacul & Visual & & $\mathrm{BoS}$ & & $\mathrm{KK}$ & \\
\hline & & 37 & Caping & Visual & & $\mathrm{BoS}$ & & KK & \\
\hline \multirow{17}{*}{$\begin{array}{l}\text { Alam \& } \\
\text { geografis }\end{array}$} & \multirow{4}{*}{$\begin{array}{l}\text { Kawasan tempat } \\
\text { tinggal }\end{array}$} & 38 & Perumahan kota & Visual & Adit & & & & \\
\hline & & 39 & Perkampungan & Visual & Adit & & $\mathrm{KS}$ & & SJ \\
\hline & & 40 & Pedesaan & Visual & & $\mathrm{BoS}$ & & $\mathrm{KK}$ & \\
\hline & & 41 & Pecinan & Visual & & $\mathrm{BoS}$ & & & \\
\hline & Pusat kota & 42 & $\begin{array}{l}\text { Gedung-gedung bertingkat } \\
\text { Jakarta }\end{array}$ & Visual & Adit & & & & \\
\hline & Area pendidikan & 43 & Gedung sekolah SD & Visual & & & & & \\
\hline & & 44 & Jakarta & Visual & Adit & & KS & & SJ \\
\hline & & 45 & Bandung & Visual & & & KS & & \\
\hline & Nama kota & 46 & Surabaya & Visual & & $\mathrm{BoS}$ & & & \\
\hline & & 47 & Kendal & Visual & & & & & SJ \\
\hline & & 48 & Bali & Visual & & & $\mathrm{KS}$ & & \\
\hline & & 49 & Pasar kota lama & Visual & & $\mathrm{BoS}$ & & & \\
\hline & Area komersial & 50 & Pasar tradisional & Visual & & $\mathrm{BoS}$ & & & \\
\hline & & 51 & Ruko modern & Visual & Adit & & & & \\
\hline & & 52 & Hutan tropis & Visual & & & & $\mathrm{KK}$ & \\
\hline & Kondisi alam & 53 & Sungai di pinggir sawah & Visual & & $\mathrm{BoS}$ & & KK & \\
\hline & & 54 & Iklim Tropis & Visual & Adit & $\mathrm{BoS}$ & KS & KK & SJ \\
\hline
\end{tabular}




\begin{tabular}{|c|c|c|c|c|c|c|c|c|c|}
\hline Kategori & Jenis & No. & Item/Bentuk & $\begin{array}{c}\text { Unsur } \\
\text { Animasi }\end{array}$ & \multicolumn{5}{|c|}{ Kemunculan } \\
\hline \multirow{36}{*}{$\begin{array}{c}\text { Bahasa \& } \\
\text { Komunikasi }\end{array}$} & \multirow{4}{*}{ Bahasa } & 55 & Bahasa Indonesia & Audio & Adit & $\mathrm{BoS}$ & $\mathrm{KS}$ & KK & SJ \\
\hline & & 56 & Bahasa Indonesia ejaan lama & Audio & & BoS & & & $\mathrm{SJ}$ \\
\hline & & 57 & Bahasa daerah & Audio & Adit & BoS & $\mathrm{KS}$ & & $\mathrm{SJ}$ \\
\hline & & 58 & Dialek lokal & Audio & Adit & BoS & $\mathrm{KS}$ & & $\mathrm{SJ}$ \\
\hline & \multirow{5}{*}{ Gaya bahasa } & 59 & Pantun & Audio & Adit & & & & \\
\hline & & 60 & Науyаa... & Audio & & & $\mathrm{KS}$ & & \\
\hline & & 61 & Sok Britist & Audio & & & & & $\mathrm{SJ}$ \\
\hline & & 62 & Merdekaa!!! & Audio & & BoS & & & \\
\hline & & 63 & Plesetan & Audio & & & & & $\mathrm{SJ}$ \\
\hline & \multirow{27}{*}{ Teks } & 64 & Warung Tahu Sumedang & Visual & Adit & & & & \\
\hline & & 65 & Kuras WC & Visual & Adit & & & & \\
\hline & & 66 & Bakso Sari Rasa & Visual & Adit & & & & \\
\hline & & 67 & Taksi & Visual & Adit & & & & \\
\hline & & 68 & Halte & Visual & Adit & & & & \\
\hline & & 69 & Plat nomor kendaraan & Visual & Adit & & & & \\
\hline & & 70 & Kampung rambutan & Visual & Adit & & & & \\
\hline & & 71 & Sedang sholat & Visual & Adit & & & & \\
\hline & & 72 & Warung pecel lele & Visual & Adit & & & & \\
\hline & & 73 & Rumah makan Jarwo & Visual & Adit & & & & \\
\hline & & 74 & Tambal Ban Sopo & Visual & Adit & & & & \\
\hline & & 75 & Warteg Gaul & Visual & Adit & & & & \\
\hline & & 76 & Djoeal Minyak & Visual & & $\mathrm{BoS}$ & & & \\
\hline & & 77 & Hotel Yamato & Visual & & BoS & & & \\
\hline & & 78 & Merdekaa!!! & Visual & & BoS & & & \\
\hline & & 79 & Freedom for All Nation & Visual & & BoS & & & \\
\hline & & 80 & Milik RI & Visual & & BoS & & & \\
\hline & & 81 & Kerupuk & Visual & & & $\mathrm{KS}$ & & \\
\hline & & 82 & Warung Bu Inah & Visual & & & $\mathrm{KS}$ & & \\
\hline & & 83 & Terminal Pulogadung & Visual & & & $\mathrm{KS}$ & & \\
\hline & & 84 & SD Negeri Jakarta & Visual & & & $\mathrm{KS}$ & & \\
\hline & & 85 & Pos Kamling & Visual & & & $\mathrm{KS}$ & & \\
\hline & & 86 & Selamat datang di Bali & Visual & & & $\mathrm{KS}$ & & \\
\hline & & 87 & Garudajaya & Visual & & & & & $\mathrm{SJ}$ \\
\hline & & 88 & Sedot Tinja & Visual & & & & & $\mathrm{SJ}$ \\
\hline & & 89 & Pos Polisi & Visual & & & & & $\mathrm{SJ}$ \\
\hline & & 90 & Warung 09 & Visual & & & & & $\mathrm{SJ}$ \\
\hline
\end{tabular}




\begin{tabular}{|c|c|c|c|c|c|c|c|c|c|}
\hline Kategori & Jenis & No. & Item/Bentuk & $\begin{array}{l}\text { Unsur } \\
\text { Animasi }\end{array}$ & \multicolumn{5}{|c|}{ Kemunculan } \\
\hline \multirow{32}{*}{$\begin{array}{c}\text { Bangunan, } \\
\text { struktur \& } \\
\text { penanda }\end{array}$} & \multirow{22}{*}{ Bangunan umum } & 91 & Pos ronda & Visual & Adit & & & & \\
\hline & & 92 & Halte & Visual & Adit & & & & \\
\hline & & 93 & Jembatan kayu & Visual & Adit & & & & \\
\hline & & 94 & Toko kelontong & Visual & Adit & & $\mathrm{KS}$ & & SJ \\
\hline & & 95 & Sekolah dasar & Visual & & & KS & & \\
\hline & & 96 & Halaman sekolah & Visual & & & KS & & \\
\hline & & 97 & Ruang kelas & Visual & & & $\mathrm{KS}$ & & \\
\hline & & 98 & Lapangan sepakbola kampung & Visual & Adit & & & & \\
\hline & & 99 & Lapangan kosong & Visual & Adit & & & & \\
\hline & & 100 & Monas & Visual & & & & & SJ \\
\hline & & 101 & Pos polisi & Visual & & & & & SJ \\
\hline & & 102 & Saung & Visual & & BoS & $\mathrm{KS}$ & KK & \\
\hline & & 103 & Terminal bis & Visual & & & $\mathrm{KS}$ & & \\
\hline & & 104 & Stasiun kereta api & Visual & & BoS & & & \\
\hline & & 105 & $\begin{array}{l}\text { Gedung Syahbandar Tanjung } \\
\text { Perak }\end{array}$ & Visual & & $\mathrm{BoS}$ & & & \\
\hline & & 106 & Jembatan merah & Visual & & BoS & & & \\
\hline & & 107 & Sumur & Visual & & BoS & & KK & \\
\hline & & 108 & Warung Tahu Sumedang & Visual & Adit & & & & \\
\hline & & 109 & Warung pecel lele & Visual & Adit & & & & \\
\hline & & 110 & Warteg & Visual & Adit & & & & \\
\hline & & 111 & Warung tradisional & Visual & & BoS & & & \\
\hline & & 112 & Hotel yamato & Visual & & BoS & & & \\
\hline & \multirow{10}{*}{ Jenis material alam } & 113 & Rumah pedesaan & Visual & & BoS & KS & KK & \\
\hline & & 114 & Rumah gadang & Visual & & & & & SJ \\
\hline & & 115 & Rumah joglo & Visual & & BoS & & & \\
\hline & & 116 & Balai besar Joglo & Visual & & BoS & & & \\
\hline & & 117 & Perumahan modern & Visual & Adit & & & & \\
\hline & & 118 & Rumah kampung & Visual & Adit & & KS & & SJ \\
\hline & & 119 & Atap daun kelapa & Visual & & $\mathrm{BoS}$ & & & \\
\hline & & 120 & Atap Genteng & Visual & Adit & BoS & KS & KK & SJ \\
\hline & & 121 & Alas lantai tanah & Visual & & $\mathrm{BoS}$ & & & \\
\hline & & 122 & Dinding gedek & Visual & & $\mathrm{BoS}$ & & & \\
\hline \multirow{24}{*}{ Gagasan } & \multirow{12}{*}{ Nilai-nilai } & 123 & Kejujuran & Naratif & Adit & $\mathrm{BoS}$ & $\mathrm{KS}$ & KK & SJ \\
\hline & & 124 & Tolong menolong & Naratif & Adit & $\mathrm{BoS}$ & & KK & SJ \\
\hline & & 125 & Tanggung jawab & Naratif & Adit & BoS & & KK & SJ \\
\hline & & 126 & Sabar & Naratif & Adit & $\mathrm{BoS}$ & & KK & SJ \\
\hline & & 127 & Rasa malu & Naratif & Adit & $\mathrm{BoS}$ & & KK & SJ \\
\hline & & 128 & Toleransi & Naratif & & & KS & KK & \\
\hline & & 129 & Hormat-menghormati & Naratif & Adit & BoS & $\mathrm{KS}$ & & SJ \\
\hline & & 130 & Tidak tamak/sederhana & Naratif & Adit & & & & SJ \\
\hline & & 131 & Cinta tanah air & Naratif & & BoS & & & SJ \\
\hline & & 132 & Rela berkorban & Naratif & Adit & BoS & & & SJ \\
\hline & & 133 & Kepahlawanan & Naratif & & BoS & & & SJ \\
\hline & & 134 & Kesetaraan & Naratif & & BoS & & & \\
\hline & & 135 & Tidak mencuri & Naratif & & & KS & & \\
\hline & & 136 & Menepati janji & Naratif & Adit & BoS & & & \\
\hline & & 137 & Mengucapkan terima kasih & Naratif & Adit & $\mathrm{BoS}$ & KS & & SJ \\
\hline & & 138 & Pamit sebelum pergi & Naratif & Adit & BoS & KS & & SJ \\
\hline & Norma & 139 & $\begin{array}{l}\text { Saling menyapa/memberikan } \\
\text { salam }\end{array}$ & Naratif & Adit & $\mathrm{BoS}$ & $\mathrm{KS}$ & & \\
\hline & & 140 & Saling menasehati & Naratif & Adit & BoS & $\mathrm{KS}$ & KK & SJ \\
\hline & & 141 & Menghormati yang lebih tua & Naratif & Adit & $\mathrm{BoS}$ & $\mathrm{KS}$ & & SJ \\
\hline & & 142 & Mudah memaafkan & Naratif & Adit & $\mathrm{BoS}$ & $\mathrm{KS}$ & & SJ \\
\hline & & 143 & Saling berbagi & Naratif & Adit & BoS & KS & & SJ \\
\hline & & 144 & Setia kawan & Naratif & Adit & $\mathrm{BoS}$ & $\mathrm{KS}$ & KK & SJ \\
\hline & & 145 & Musyawarah & Naratif & Adit & $\mathrm{BoS}$ & $\mathrm{KS}$ & KK & SJ \\
\hline & Adat istiadat & 146 & Gotong royong & Naratif & Adit & BoS & KS & KK & SJ \\
\hline
\end{tabular}




\begin{tabular}{|c|c|c|c|c|c|c|c|c|c|}
\hline Kategori & Jenis & No. & Item/Bentuk & $\begin{array}{l}\text { Unsur } \\
\text { Animasi }\end{array}$ & \multicolumn{5}{|c|}{ Kemunculan } \\
\hline \multirow{29}{*}{ Gerakan } & \multirow{7}{*}{ Aktivitas umum } & 147 & Duduk bersila & Gerakan & & & & KK & \\
\hline & & 148 & Bersalaman & Gerakan & Adit & $\mathrm{BoS}$ & & KK & SJ \\
\hline & & 149 & Makan pakai tangan kanan & Gerakan & & BoS & & & \\
\hline & & 150 & $\begin{array}{l}\text { Mengambil/menerima barang } \\
\text { dengan tangan kanan }\end{array}$ & Gerakan & Adit & Bos & $\mathrm{KS}$ & KK & SJ \\
\hline & & 151 & Ibu-ibu ngerumpi & Gerakan & Adit & & & & $\mathrm{SJ}$ \\
\hline & & 152 & $\begin{array}{l}\text { Mengambil layangan dengan } \\
\text { kavu/bambu }\end{array}$ & Gerakan & & & & & SJ \\
\hline & & 153 & $\begin{array}{l}\text { Membawa barang bawaan di } \\
\text { punggung }\end{array}$ & Gerakan & & BoS & & & \\
\hline & & 154 & Mengucapkan selamat lebaran & Gerakan & Adit & & & & \\
\hline & & 155 & $\begin{array}{l}\text { Membangunkan keluarga untuk } \\
\text { sahur }\end{array}$ & Gerakan & & & $\mathrm{KS}$ & & \\
\hline & & 156 & Menjemur baju di luar rumah & Gerakan & Adit & & & KK & \\
\hline & & 157 & Premanisme & Gerakan & Adit & & & & \\
\hline & & 158 & Kasbon & Gerakan & Adit & & $\mathrm{KS}$ & & $\mathrm{SJ}$ \\
\hline & & 159 & Goyang dangdut & Gerakan & Adit & & & & SJ \\
\hline & Kehiasaan & 160 & Ingin cepat pulang sekolah & Gerakan & & & $\mathrm{KS}$ & & \\
\hline & Kebiasaan & 161 & Ingin cepat libur sekolah & Gerakan & & & $\mathrm{KS}$ & & \\
\hline & & 162 & Tidak suka membaca & Gerakan & & & KS & & \\
\hline & & 163 & Makan mie instan mentah & Gerakan & & & & & $\mathrm{SJ}$ \\
\hline & & 164 & Anak SD ngompol & Gerakan & & & & & SJ \\
\hline & & 165 & Bullying & Gerakan & & & & & $\mathrm{SJ}$ \\
\hline & & 166 & Kaca spion 1 biji & Gerakan & Adit & & & & \\
\hline & & 167 & $\begin{array}{l}\text { Memakai payung dari daun } \\
\text { pisang }\end{array}$ & Gerakan & & $\mathrm{BoS}$ & & & \\
\hline & & 168 & $\begin{array}{l}\text { Mengangkat kedua tangan saat } \\
\text { berdoa }\end{array}$ & Gerakan & Adit & BoS & KS & & \\
\hline & & 169 & $\begin{array}{l}\text { Mengangkat tangan saat } \\
\text { mengucapkan salam }\end{array}$ & Gerakan & Adit & $\mathrm{BoS}$ & $\mathrm{KS}$ & & SJ \\
\hline & & 170 & $\begin{array}{l}\text { Mengusapkan tangan di dada } \\
\text { saat mengucapkan istigfar }\end{array}$ & Gerakan & Adit & & & & \\
\hline & Gerakan tangan & 171 & $\begin{array}{l}\text { Mengepalkan tangan saat } \\
\text { mengucapkan kalimat } \\
\text { "merdeka" }\end{array}$ & Gerakan & & Bos & & & \\
\hline & & 172 & Tepok jidat & Gerakan & Adit & BoS & $\mathrm{KS}$ & & $\mathrm{SJ}$ \\
\hline & & 173 & Mengacungkan jari jempol & Gerakan & Adit & & & & \\
\hline & & 174 & $\begin{array}{l}\text { Mengusap kepala bagian } \\
\text { belakang }\end{array}$ & Gerakan & Adit & & KS & & SJ \\
\hline & & 175 & Menaruh tangan di belakang & Gerakan & Adit & BoS & & KK & \\
\hline
\end{tabular}




\begin{tabular}{|c|c|c|c|c|c|c|c|c|c|}
\hline Kategori & Jenis & No. & Item/Bentuk & $\begin{array}{c}\text { Unsur } \\
\text { Animasi }\end{array}$ & \multicolumn{5}{|c|}{ Kemunculan } \\
\hline \multirow{26}{*}{ Karakter } & \multirow{2}{*}{ Suara orang } & 176 & Suara Artis lokal & Audio & Adit & & & & SJ \\
\hline & & 177 & Logat etnis/daerah & Audio & Adit & $\mathrm{BoS}$ & KS & KK & SJ \\
\hline & \multirow{14}{*}{ Tokoh lokal } & 178 & Tukang sayur & Visual & Adit & & & & \\
\hline & & 179 & Tukang bakso & Visual & Adit & BoS & KS & & \\
\hline & & 180 & Tukang es lilin & Visual & & & $\mathrm{KS}$ & & \\
\hline & & 181 & Tukang becak & Visual & Adit & $\mathrm{BoS}$ & & & \\
\hline & & 182 & Tukang Loper koran \& majalah & Visual & & & & & SJ \\
\hline & & 183 & Tukang sedot tinja & Visual & & & & & SJ \\
\hline & & 184 & Empu keris & Visual & & & & KK & \\
\hline & & 185 & Hansip & Visual & & & $\mathrm{KS}$ & & \\
\hline & & 186 & Satpam & Visual & & & & & SJ \\
\hline & & 187 & Siswa SD & Visual & & & $\mathrm{KS}$ & & \\
\hline & & 188 & Veteran & Visual & & & & & SJ \\
\hline & & 189 & Petani & Visual & & $\mathrm{BoS}$ & & KK & \\
\hline & & 190 & Artis lokal & Visual & Adit & & & & SJ \\
\hline & & 191 & Pedagang pasar tradisional & Visual & & $\mathrm{BoS}$ & & KK & \\
\hline & \multirow{6}{*}{ Tokoh Sejarah } & 192 & Buto Asyuro & Visual & & & & KK & \\
\hline & & 193 & Sutan syahrir & Visual & & BoS & & & \\
\hline & & 194 & Bung tomo & Visual & & BoS & & & \\
\hline & & 195 & Sukarno & Visual & & BoS & & & \\
\hline & & 196 & Hatta & Visual & & BoS & & & \\
\hline & & 197 & Jenderal Mallaby & Visual & & BoS & & & \\
\hline & \multirow{2}{*}{ Suku } & 198 & Suku Bangsa pribumi & Visual & Adit & & KS & & \\
\hline & & 199 & Etnis cina & Visual & & $\mathrm{BoS}$ & $\mathrm{KS}$ & & \\
\hline & \multirow{2}{*}{ Hewan } & 200 & Burung Gereja Erasia & Visual & Adit & & & & \\
\hline & & 201 & Lutung & Visual & & Bos & & & \\
\hline \multirow{13}{*}{ Kenegaraan } & \multirow{6}{*}{$\begin{array}{c}\text { Organisasi \& } \\
\text { Aparat }\end{array}$} & 202 & $\mathrm{Tni} / \mathrm{tkr} / \mathrm{bkr}$ & Visual & & $\mathrm{BoS}$ & & & \\
\hline & & 203 & Satpol PP & Visual & & & & & SJ \\
\hline & & 204 & Densus 88 & Visual & & & & & SJ \\
\hline & & 205 & Polisi & Visual & & & & & SJ \\
\hline & & 206 & Sipir penjara & Visual & & & & & SJ \\
\hline & & 207 & Pns & Visual & & & & & SJ \\
\hline & \multirow{7}{*}{ Simbol negara } & 208 & Mata uang & Visual & Adit & & KS & & \\
\hline & & 209 & Burung garuda & Visual & Adit & & & & SJ \\
\hline & & 210 & Peta Indonesia & Visual & & & KS & & SJ \\
\hline & & 211 & Patung presiden RI & Visual & & & & & SJ \\
\hline & & 212 & Foto pahlawan nasional & Visual & & & $\mathrm{KS}$ & & SJ \\
\hline & & 213 & Bendera RI & Visual & & $\mathrm{BoS}$ & KS & KK & SJ \\
\hline & & 214 & Atribut kemerdekaan & Visual & & BoS & & & \\
\hline \multirow{7}{*}{ Kesenian } & \multirow{3}{*}{ Musik tari-tarian } & 215 & Tari Tortor & Audio & & & & & SJ \\
\hline & & 216 & Reog Ponorogo & Audio & & $\mathrm{BoS}$ & & & \\
\hline & & 217 & Tari Remo & Audio & & $\mathrm{BoS}$ & & & \\
\hline & \multirow{3}{*}{$\begin{array}{l}\text { Gerakan tari-tarian } \\
\text { tradisional }\end{array}$} & 218 & Tari Tortor & Gerakan & & & & & SJ \\
\hline & & 219 & Reog Ponorogo & Gerakan & & BoS & & & \\
\hline & & 220 & Tari Remo & Gerakan & & $\mathrm{BoS}$ & & & \\
\hline & Topeng tradisional & 221 & Topeng Malangan & Visual & & & & KK & \\
\hline
\end{tabular}




\begin{tabular}{|c|c|c|c|c|c|c|c|c|c|}
\hline Kategori & Jenis & No. & Item/Bentuk & $\begin{array}{l}\text { Unsur } \\
\text { Animasi }\end{array}$ & \multicolumn{5}{|c|}{ Kemunculan } \\
\hline \multirow{36}{*}{ Kostum } & \multirow{5}{*}{ Pakaian muslim } & 222 & Kerudung muslimah & visual & Adit & $\overline{\mathrm{BoS}}$ & $\overline{K S}$ & $\overline{\mathrm{KK}}$ & SJ \\
\hline & & 223 & Baju koko & visual & Adit & & & & \\
\hline & & 224 & Surban & visual & Adit & BoS & & & \\
\hline & & 225 & Songkok hitam & visual & & BoS & KS & KK & $\mathrm{SJ}$ \\
\hline & & 226 & Sarung & visual & Adit & BoS & KS & & SJ \\
\hline & & 227 & Baju adat betawi & visual & Adit & & & & $\mathrm{SJ}$ \\
\hline & & 228 & Batik & visual & & & KS & KK & \\
\hline & & 229 & Blangkon & visual & & $\mathrm{BoS}$ & KS & & \\
\hline & & 230 & Kebaya & visual & & BoS & $\mathrm{KS}$ & & $\mathrm{SJ}$ \\
\hline & & 231 & Sanggul rambut & visual & & & KS & & \\
\hline & Pakaian tradisional & 232 & Beskap & visual & & BoS & & & \\
\hline & & 233 & Kemben & visual & & & & KK & \\
\hline & & 234 & Baju raja & visual & & Bos & & & \\
\hline & & 235 & Atribupewayangan & visual & & Bos & & & \\
\hline & & 236 & Baju tari Remo & visual & & & & & \\
\hline & & 237 & Baju tari reog Ponorogo & visual & & & & & \\
\hline & & 238 & Kaos oblong Bali & visual & Adit & & KS & & \\
\hline & & 239 & Anak tudung & visual & Adit & & & KK & \\
\hline & & 240 & Baju tukang bakso & visual & Adit & & $\mathrm{KS}$ & & \\
\hline & Pakaian sehari-hari & 241 & Baju penjual sayur & visual & Adit & Bos & & & \\
\hline & & 242 & Sandal jepit hijau & visual & & & & & SJ \\
\hline & & 243 & Baju orang biasa/umum & visual & Adit & $\mathrm{BoS}$ & $\mathrm{KS}$ & KK & SJ \\
\hline & & 244 & Daster & visual & & & $\mathrm{KS}$ & & \\
\hline & & 245 & Hansip & visual & & & KS & & \\
\hline & & 246 & Satpam & visual & & & & & $\mathrm{SJ}$ \\
\hline & & 247 & Satpol PP & visual & & & & & SJ \\
\hline & & 248 & Densus 88 & visual & & & & & $\mathrm{SJ}$ \\
\hline & & 249 & Pns & visual & & & & & $\mathrm{SJ}$ \\
\hline & Seragam & 250 & Veteran & visual & & & & & SJ \\
\hline & & 251 & Polisi & visual & & & & & $\mathrm{SJ}$ \\
\hline & & 252 & Baju tentara & visual & & $\mathrm{BoS}$ & & & \\
\hline & & 253 & Pramuka & Visual & Adit & & & & \\
\hline & & 254 & Seragam SD & visual & & & $\mathrm{KS}$ & & $\mathrm{SJ}$ \\
\hline & & 255 & Sipir penjara & visual & & & & & SJ \\
\hline & Pakaian tokoh & 256 & Hantu lokal & visual & & & & & SJ \\
\hline & mistis & 257 & Dukun & visual & & & & & SJ \\
\hline
\end{tabular}




\begin{tabular}{|c|c|c|c|c|c|c|c|c|c|}
\hline Kategori & Jenis & No. & Item/Bentuk & $\begin{array}{l}\text { Unsur } \\
\text { Animasi }\end{array}$ & \multicolumn{5}{|c|}{ Kemunculan } \\
\hline \multirow{32}{*}{ Kuliner } & \multirow{24}{*}{$\begin{array}{c}\text { Makanan \& } \\
\text { Minuman }\end{array}$} & 258 & Sayur asam & Visual & Adit & & & & \\
\hline & & 259 & Nasi ikan goreng & Visual & Adit & & & KK & \\
\hline & & 260 & Perkedel & Visual & & & KS & & \\
\hline & & 261 & Sayur kacang santan & Visual & & & KS & & \\
\hline & & 262 & Jengkol & Visual & & & KS & & SJ \\
\hline & & 263 & Tempe & Visual & & $\mathrm{BoS}$ & KS & KK & \\
\hline & & 264 & Nasi & Visual & Adit & BoS & KS & KK & \\
\hline & & 265 & Tahu \& tahu Sumedang & Visual & Adit & BoS & & KK & \\
\hline & & 266 & Kotak krupuk & Visual & Adit & & KS & KK & \\
\hline & & 267 & Kue kering lebaran & Visual & Adit & & & & \\
\hline & & 268 & Khong Guan & Visual & & & & & SJ \\
\hline & & 269 & Mi instan & Visual & & & & & SJ \\
\hline & & 270 & Roti goreng & Visual & & & & & SJ \\
\hline & & 271 & Ketupat & Visual & Adit & & & & \\
\hline & & 272 & Kolak pisang & Visual & & & KS & & \\
\hline & & 273 & Singkong goreng & Visual & & & KS & & \\
\hline & & 274 & Keripik & Visual & & & & & SJ \\
\hline & & 275 & Kopi hitam & Visual & & BoS & & & SJ \\
\hline & & 276 & Klepon & Visual & & BoS & & & \\
\hline & & 277 & Tewol & Visual & & BoS & & & \\
\hline & & 278 & Pisang & Visual & & $\mathrm{BoS}$ & & & \\
\hline & & 279 & Bakso & Visual & Adit & & KS & & \\
\hline & & 280 & Ayam bakar & Visual & & & & KK & \\
\hline & & 281 & Air putih & Visual & & BoS & & KK & \\
\hline & \multirow{8}{*}{ Peralatan makanan } & 282 & Wakul nasi tradisional & Visual & & BoS & KS & & \\
\hline & & 283 & Gerobak bakso & Visual & Adit & BoS & KS & & SJ \\
\hline & & 284 & Mangkok bakso cap ayam & Visual & Adit & & & & \\
\hline & & 285 & Teko \& gelas hijau & Visual & Adit & BoS & & & SJ \\
\hline & & 286 & Tudung nasi tradisional & Visual & & & KS & & \\
\hline & & 287 & Perabot masakan tradisional & Visual & & BoS & & & \\
\hline & & 288 & Kendi air putih & Visual & & & & KK & \\
\hline & & 289 & Bungkus daun pisang & Visual & Adit & BoS & & KK & \\
\hline \multirow{22}{*}{ Permainan } & \multirow{4}{*}{$\begin{array}{l}\text { Suara alat } \\
\text { permainan } \\
\text { tradisional }\end{array}$} & 290 & Engklek/lompat kotak & Audio & Adit & BoS & & & \\
\hline & & 291 & Rangku alu/lompat bambu & Audio & Adit & & & & \\
\hline & & 292 & Kelereng & Audio & & & & & SJ \\
\hline & & 293 & Lompat tali & Audio & & BoS & & & SJ \\
\hline & & 294 & Ayunan ban bekas & Gerakan & Adit & & & & \\
\hline & & 295 & Engklek/lompat kotak & Gerakan & Adit & BoS & & & \\
\hline & & 296 & Rangku alu/lompat bambu & Gerakan & Adit & & & & \\
\hline & $\begin{array}{l}\text { Gerakan permainan } \\
\text { tradisional }\end{array}$ & 297 & Kelereng & Gerakan & & & & & SJ \\
\hline & & 298 & Layangan & Gerakan & & & & & SJ \\
\hline & & 299 & Lompat tali & Gerakan & & BoS & & & SJ \\
\hline & & 300 & Layangan & Gerakan & & BoS & & & \\
\hline & & 301 & Sepakbola & Gerakan & Adit & & & & \\
\hline & Gerakan olahraga & 302 & Kasti & Gerakan & Adit & & & & \\
\hline & & 303 & Ayunan ban bekas & Visual & Adit & & & & \\
\hline & & 304 & Engklek/lompat kotak & Visual & Adit & BoS & & & \\
\hline & & 305 & Rangku alu/lompat bambu & Visual & Adit & & & & \\
\hline & Permainan & 306 & Kelereng & Visual & & & & & SJ \\
\hline & & 307 & Layangan & Visual & & & & & SJ \\
\hline & & 308 & Lompat tali & Visual & & $\mathrm{BoS}$ & & & SJ \\
\hline & & 309 & Layangan & Visual & & $\mathrm{BoS}$ & & & \\
\hline & & 310 & Sepakbola Kampung & Visual & Adit & & & & \\
\hline & Olanraga & 311 & Kasti & Visual & Adit & & & & \\
\hline
\end{tabular}




\begin{tabular}{|c|c|c|c|c|c|c|c|c|c|}
\hline Kategori & Jenis & No. & Item/Bentuk & $\begin{array}{c}\text { Unsur } \\
\text { Animasi }\end{array}$ & \multicolumn{5}{|c|}{ Kemunculan } \\
\hline \multirow{24}{*}{ Properti } & \multirow{4}{*}{ Senjata tradisional } & 312 & Bambu runcing & Visual & & $\mathrm{BoS}$ & & & \\
\hline & & 313 & Ketapel & Visual & & BoS & & & \\
\hline & & 314 & Keris & Visual & & BoS & & & \\
\hline & & 315 & Arit/clurit & Visual & & $\mathrm{BoS}$ & & & \\
\hline & \multirow{20}{*}{ Properti keseharian } & 316 & Gerobak kosong & Visual & Adit & & & & \\
\hline & & 317 & Gerobak sayur & Visual & Adit & & & & \\
\hline & & 318 & Gas LPG & Visual & Adit & & & & $\mathrm{SJ}$ \\
\hline & & 319 & Spanduk & Visual & Adit & & & & \\
\hline & & 320 & Papan tulis hitam & Visual & & & KS & & \\
\hline & & 321 & Umbul-umbul & Visual & Adit & & & & \\
\hline & & 322 & Tempat sampah akhir & Visual & Adit & & & & \\
\hline & & 323 & Poster di dinding & Visual & Adit & & & & \\
\hline & & 324 & Sticker di tiang listrik & Visual & Adit & & & & \\
\hline & & 325 & Poster politik & Visual & Adit & & & & \\
\hline & & 326 & Tangga bambu & Visual & Adit & BoS & & & \\
\hline & & 327 & Kipas bambu & Visual & & & KS & & SJ \\
\hline & & 328 & Sekat rotan & Visual & & & $\mathrm{KS}$ & & \\
\hline & & 329 & Mesin jahit & Visual & & & & & SJ \\
\hline & & 330 & Radio lama & Visual & & BoS & & & \\
\hline & & 331 & Tikar & Visual & & BoS & & & \\
\hline & & 332 & Tempat tidur kayu & Visual & & BoS & & & \\
\hline & & 333 & Tas ayam & Visual & & BoS & & & \\
\hline & & 334 & Lampu minyak & Visual & & BoS & & KK & \\
\hline & & 335 & Perabot rumah tempo dulu & Visual & & BoS & & & \\
\hline \multirow{8}{*}{ Sejarah } & \multirow[b]{2}{*}{ Pidato } & 336 & Suara pidato Bung Tomo & Audio & & Bos & & & \\
\hline & & 337 & $\begin{array}{l}\text { Suara pidato Proklamasi Bung } \\
\text { Karno }\end{array}$ & Audio & & Bos & & & \\
\hline & \multirow{2}{*}{$\begin{array}{l}\text { Suara ambience } \\
\text { peristiwa sejarah }\end{array}$} & 338 & $\begin{array}{l}\text { Perobekan bendera Belanda di } \\
\text { Hotel Yamato }\end{array}$ & Audio & & BoS & & & \\
\hline & & 339 & Perang 10 November 1945 & Audio & & BoS & & & \\
\hline & \multirow{4}{*}{ Kejadian sejarah } & 340 & $\begin{array}{l}\text { Perobekan bendera Belanda di } \\
\text { Hotel Yamato }\end{array}$ & visual & & BoS & & & \\
\hline & & 341 & Perang 10 November 1945 & visual & & BoS & & & \\
\hline & & 342 & Proklamasi & visual & & $\mathrm{BoS}$ & & & \\
\hline & & 343 & Pidato Bung Tomo & visual & & BoS & & & \\
\hline \multirow{14}{*}{ Suara } & \multirow{2}{*}{ Suara alat musik } & 344 & Rebana & Audio & Adit & & & & \\
\hline & & 345 & Bedug & Audio & Adit & & & & \\
\hline & Musik dangdut & 346 & Musik dangdut & Audio & & & & & $\mathrm{SJ}$ \\
\hline & \multirow{2}{*}{ Musik tradisional } & 347 & Musik tanjidor & Audio & Adit & & & & \\
\hline & & 348 & Musik gamelan & Audio & & & KS & KK & \\
\hline & \multirow{2}{*}{ Lagu tradisional } & 349 & Lagu Ondel-Ondel & Audio & & & & & $\mathrm{SJ}$ \\
\hline & & 350 & Lagu pengiring tari batak & Audio & & & & & SJ \\
\hline & \multirow{5}{*}{$\begin{array}{c}\text { Ambience } \\
\text { Lingkungan }\end{array}$} & 351 & Suara orang menyapu halaman & Audio & & & KS & & \\
\hline & & 352 & Suara burung di pagi hari & Audio & Adit & BoS & KS & KK & \\
\hline & & 353 & Suara azan & Audio & Adit & BoS & KS & & \\
\hline & & 354 & $\begin{array}{l}\text { Suara orang membangunkan } \\
\text { sahur }\end{array}$ & Audio & & & $\mathrm{KS}$ & & \\
\hline & & 355 & $\begin{array}{l}\text { Suara jengkerik pada malam } \\
\text { hari }\end{array}$ & Audio & & Bos & KS & & \\
\hline & \multirow{2}{*}{ Alat musik } & 356 & Rebana & Visual & Adit & & & & \\
\hline & & 357 & Bedug & Visual & Adit & & & & \\
\hline
\end{tabular}




\begin{tabular}{|c|c|c|c|c|c|c|c|c|}
\hline Kategori & Jenis & No. & Item/Bentuk & $\begin{array}{c}\text { Unsur } \\
\text { Animasi }\end{array}$ & \multicolumn{4}{|c|}{ Kemunculan } \\
\hline \multirow{18}{*}{ Transportasi } & \multirow{7}{*}{$\begin{array}{l}\text { Suara alat } \\
\text { transportasi }\end{array}$} & 358 & Bajaj & Audio & Adit & & & SJ \\
\hline & & 359 & Angkot & Audio & Adit & & & SJ \\
\hline & & 360 & Kopaja & Audio & & & & SJ \\
\hline & & 361 & Dokar & Audio & & BoS & & \\
\hline & & 362 & Cikar & Audio & & BoS & KK & \\
\hline & & 363 & Sepeda onthel & Audio & & $\mathrm{BoS}$ & & \\
\hline & & 364 & Kereta api lama & Audio & & BoS & & \\
\hline & & 365 & Bajaj & Visual & Adit & & & SJ \\
\hline & & 366 & Angkot & Visual & Adit & & & $\mathrm{SJ}$ \\
\hline & & 367 & Kopaja & Visual & & & & SJ \\
\hline & & 368 & Pangkalan ojek & Visual & Adit & & & \\
\hline & & 369 & Becak & Visual & Adit & BoS & & \\
\hline & Transportasi & 370 & Tambal ban & Visual & Adit & & & \\
\hline & & 371 & Bensin eceran & Visual & Adit & & & \\
\hline & & 372 & Dokar & Visual & & BoS & & \\
\hline & & 373 & Cikar & Visual & & BoS & KK & \\
\hline & & 374 & Sepeda onthel & Visual & & BoS & & \\
\hline & & 375 & Kereta api lama & Visual & & $\mathrm{BoS}$ & & \\
\hline & & & & & & & & \\
\hline
\end{tabular}


